\title{
Epicormics in 13-year-old Quercus petraea: small effect of provenance and large influence of branches and growth unit limits
}

\author{
${\text { Francis } \text { COLIN }^{1 *} \text {, Alexis DuCOUSSO }}^{2}$, Florence FonTAINE ${ }^{3}$ \\ ${ }^{1}$ UMR 1092 INRA-AgroParisTech, Laboratoire d'étude des Ressources Forêt-Bois, INRA-Nancy, 54280 Champenoux, France \\ ${ }^{2}$ UMR 1202 BIOGECO, genetic team, INRA, 69 route d'Arcarchon, 33612 Cestas Cedex, France \\ ${ }^{3}$ UFR Sciences, Moulin de la Housse, Laboratoire de Stress, Défenses et Reproduction des Plantes, Bâtiment 18, BP 1039, \\ 51687 Reims Cedex 2, France
}

(Received 21 April 2009; accepted 15 September 2009)

Keywords:
epicormics /
provenance /
polycyclism /
$Q_{\text {ST / }}$
Quercus petraea

Mots-clés : épicormiques / provenance / polycyclisme / $Q_{\mathrm{ST}} /$ Quercus petraea

\begin{abstract}
- The provenance effect on epicormics is poorly documented and restricted to epicormic shoots. Our objective was to characterize the relationship between epicormics and provenance on 13-year-old Quercus petraea trees, taking into account their growth traits.

- On the growth units (GU) studied, epicormics were essentially isolated buds (95\%) and they were mainly located at branch bases, secondarily on GU limits and marginally on lateral position. Provenance effect was very small on the number of epicormics and slightly larger on the number of branches and GU limits. On the contrary, the growth situation -independently from provenance- proved to have a larger effect on the 2 latter growth traits.

- Altogether, these results clearly show the predominant effect of morphological traits and thus of ontogeny. This opens important research perspectives: how growth conditions and genetics (at progeny and individual levels) influence height growth, setting and fate of axillary buds on the one hand and fate of epicormic buds inserted directly on the stem, or at branch bases on the other hand.
\end{abstract}

Résumé - Epicormiques chez le chêne sessile âgé de 13 ans : un faible effet provenance et un effet légèrement plus fort du nombre de branches et d'unités de croissance.

- L'effet provenance sur les épicormiques est peu documenté et concerne exclusivement les gourmands. Notre objectif était de caractériser l'effet de la provenance sur les épicormiques présents sur des chênes sessiles âgés de 13 ans, décrits par des marqueurs de croissance.

- Sur les unités de croissance (UC) décrites, les épicormiques sont essentiellement des bourgeons isolés (95\%), localisés à la base de branche, puis en limite d'UC et enfin en position latérale sur le tronc. L'effet provenance s'est avéré très faible sur le nombre d'épicormiques et légèrement plus fort sur le nombre de branches et d'UC développées. À l'inverse, un effet de la situation de croissance a été noté sur les deux derniers paramètres, et ceci indépendamment de la provenance.

- L'ensemble des données obtenues montre une prédominance de l'effet des marqueurs morphologiques de l'arbre sur les épicormiques, et donc de l'ontogénèse. Ceci ouvre d'intéressantes perspectives de recherche : quels sont les effets des conditions de croissance et de la génétique (au niveau descendance et individuel) sur la croissance en hauteur, la mise en place et le devenir des bourgeons axillaires d'une part, et du devenir des bourgeons épicormiques, situés directement sur la tige ou en base de branches séquentielles d'autre part.

\section{INTRODUCTION}

Quercus petraea plays an important role in French and European forestry. Oak is a relatively slow growing species with extended rotations, highly estimated for its recreational value and high-value end timber-production. According to

* Corresponding author: colin@nancy.inra.fr their quality, trees are used for cleaving, sawing, firewood, and pulpwood or veneer (Jarret, 2004). For this latter use, wood quality is very important and can be reduced by several factors including crooked trunks, forking and epicormic shoots (Colin et al., 2008; Fontaine et al., 2004; Harmer, 2000).

Results obtained on different species (Church and Godman, 1966; Fink, 1980; Fontaine et al., 1999; 2001), documented that epicormics, shoots, bud clusters and very small stumps 
Table I. Description of the different sites.

\begin{tabular}{lccccc}
\hline Sites & Latitude & Longitude & Altitude & Climate & Soil \\
\hline La Petite Charnie & N 48.0878 & W 0.1611 & $150 \mathrm{~m}$ & Atlantic & Brown soil, absence or weak hydromorphy \\
Sillégny & N 48.9900 & E 6.1322 & $200 \mathrm{~m}$ & Continental & Brown soil, intermediate hydromorphy \\
\hline
\end{tabular}

Table II. Origin of the tested populations.

\begin{tabular}{|c|c|c|c|c|c|c|c|c|}
\hline Origins $=$ forests & Code & Compartment & Country & & tude & & itude & Altitude \\
\hline Sycow & 179 & $97-99,125-128$ & Poland & $\mathrm{N}$ & 51.1818 & $E$ & 17.9284 & 210 \\
\hline Sturzelbronn & 209 & 151,152 & France & $\mathrm{N}$ & 49.0317 & $\mathrm{E}$ & 7.4983 & 390 \\
\hline Bercé & 217 & 113,119 & France & $\mathrm{N}$ & 47.8131 & $\mathrm{E}$ & 0.3906 & 165 \\
\hline Longchamp & 218 & 54 & France & $\mathrm{N}$ & 47.2636 & $\mathrm{E}$ & 5.3103 & 235 \\
\hline Tronçais & 219 & 89 & France & $\mathrm{N}$ & 46.6803 & $\mathrm{E}$ & 2.8289 & 245 \\
\hline Vachères & 233 & 1 & France & $\mathrm{N}$ & 43.9833 & $\mathrm{E}$ & 5.6325 & 650 \\
\hline Bolu & 249 & 48 & Turkey & $\mathrm{N}$ & 40.9283 & $\mathrm{E}$ & 31.6781 & $900-1500$ \\
\hline
\end{tabular}

of shoots with epicormic buds named here "picots", originate from buds called "epicormic buds". Epicormic buds have mainly proventitious origin in Quercus petraea shoots. They remain latent between one and up to 40 years (Fontaine et al., 1999). A proventitious epicormic bud originates from an existing axillary bud located at the axil of a leaf, either welldeveloped or modified into scale (Stone and Stone, 1943). It can be of primary origin when it is located directly on the main axis or of secondary origin. Secondary buds were found as individuals or in clusters at the base of a primary bud, a sequential branch ("sequential" according to Barthélémy and Caraglio, 2007), an epicormic shoot (Fontaine et al., 2001).

Since the different types of epicormics originate basically from proventitious epicormic buds in $Q$. petraea, their location is linked to the height growth of the tree. Oak is characterized by a rhythmic growth that consists of several successive growth flushes composing an annual shoot (AS), this phenomenon being refered as polycyclism (Lavarenne-Allary, 1965). Early during seedlings development, up to four growth units per year (GU, see definition in Barthélémy and Caraglio, 2007) could be produced under favourable conditions such as low stand density, full light, no late frost or sufficient water availability (Heuret et al., 2000). As a consequence of both the polycyclism and the proventitious origin of epicormics, these latters can be found either at scale scars which limit GU and AS, along the growth unit or at branch base.

In oaks, a few studies have reported the occurrence of a provenance effect on rythmic growth and epicormic shoots (Harmer, 2000; Jensen, 1993; 2000; Jensen et al., 1997). But no information is available on the other epicormic formations including buds, clusters of buds and "picots".

The objective of the present study was to characterize the relationship between provenance and all the types of epicormics on 13-year-old Quercus petraea trees, taking into account their growth traits, number of AS or GU limits and sequential branches. The following assumptions were tested: (1) the more polycyclic the provenance and thus the more GU limits are found on every annual shoot, the more epicormics are present, (2) the more prestigious a provenance
Table III. General features of the tested populations at age ten years (in 1999). TH: total height in $\mathrm{cm}, \mathrm{nbBr}$ : total branch number per tree, nbFork: total number of forks per tree; Form: score form (0 poor form; 10: elite tree).

\begin{tabular}{lcccccccc}
\hline Sites & \multicolumn{3}{c}{ La Petite Charnie } & \multicolumn{3}{c}{ Sillégny } \\
\hline \multirow{3}{*}{ Sycow } & \multicolumn{1}{c}{ TH } & nbBr & nbFork & Form & TH & nbBr & nbFork & Form \\
\cline { 2 - 9 } Sturzelbronn & 29 & 14 & 0.85 & 4 & 314 & 11 & 0.5 & 7 \\
Bercé & 315 & 14 & 0.8 & 4 & 315 & 11 & 0.7 & 6 \\
Longchamp & 322 & 14 & 0.8 & 4 & 338 & 12 & 0.6 & 6 \\
Tronçais & 342 & 16 & 0.9 & 4 & 313 & 11 & 0.6 & 6 \\
Vachères & 310 & 14 & 0.9 & 4 & 309 & 10 & 0.8 & 6 \\
Bolu & 318 & 15 & 0.9 & 4 & 305 & 11 & 0.7 & 7 \\
General means & 324 & 15 & 0.9 & 4 & 322 & 12 & 0.7 & 6 \\
\hline
\end{tabular}

(known for the good quality of its wood), the less epicormics it bears.

\section{MATERIALS AND METHOD}

The sample of populations covered most of the ranges of sessile and pedunculate oaks. It contained 124 populations (107 sessile and 17 pedunculate). Three years old seedlings were planted in the sites of Sillégny and La Petite Charnie during winter 1992-1993 (Tab. I). In each site, each provenance was replicated from ten to fifteen times with 24 trees per replicate. The initial density of plantation was 1904 individuals per hectare (spacing $3 \mathrm{~m} \times 1.75 \mathrm{~m}$ ).

Epicormics were observed on only seven populations selected according to their geographical origin (Tab. II), their wood quality, their climate and their performances for bud burst, growth and architecture (Tab. III) as well as their capacity to produce mono- (provenance Sycow in Poland) or poly-cyclic annual shoots (provenance Bolu in Turkey). Population and general means of the main architectural traits for both sites are given in Table III based on an evaluation completed at age ten years (since seeding) corresponding to year 1999. We can notice that the total tree heights were very similar in both sites but the frequencies of forks and branches were slightly smaller in Sillégny 


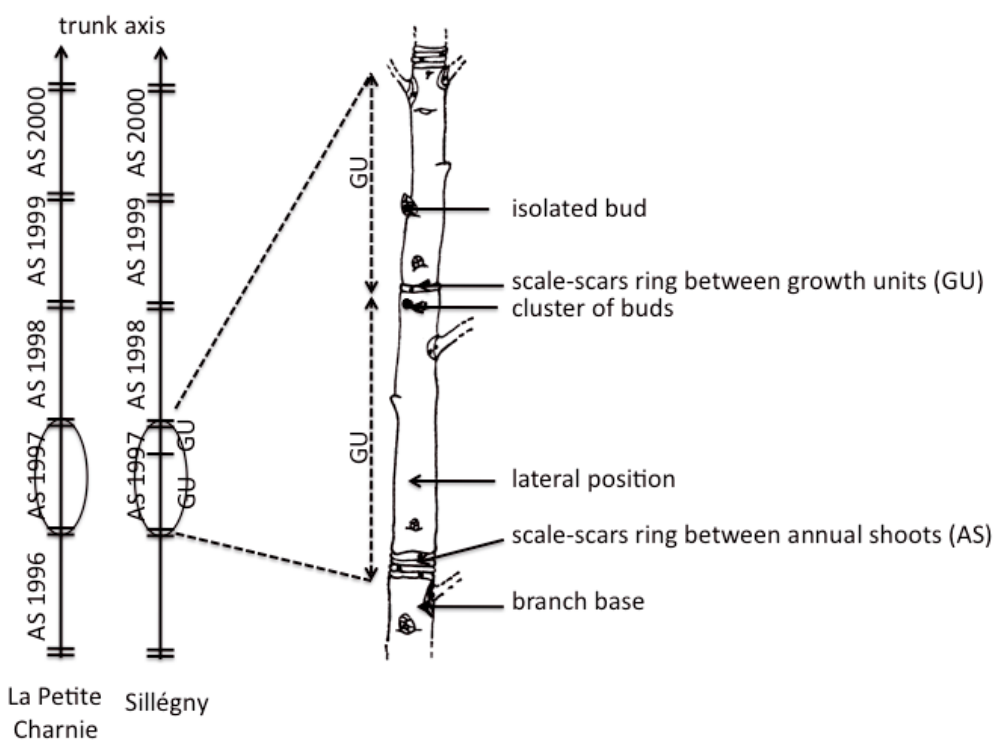

Figure 1. Diagram of shoots studied in the La Petite Charnie and in Sillégny sites. The location of the different epicormics is described on an annual shoot. AS = annual shoot; GU = growth unit.

than in La Petite Charnie leading to a better form in Sillégny. The observation of epicormics occurred during year 2002 when the trees were 13 years old.

In each site, 3 replicates were selected per provenance based on 1996' and 2001'heights: one in which oak trees have a relatively high growth rate, one with a relatively intermediate growth rate, and one with a relatively low growth rate. These levels of growth enabled to obtain as wide as possible range of length of axis described, number of branches and number of GU limits. These levels of growth constituted the "Growth" effect. As a direct consequence of this experimental option, the "Growth" effect had to be tested by nesting it in the provenance effect within each field site. Initially, 504 trees had been planted in the selected replicates but only 446 trees remained alive in La Petite Charnie and 399 in Sillégny in 2002. The difference could be explained by the fact that the Sillégny site was more hydromorphic than the La Petite Charnie site. The trunk portion studied and the number of annual shoots were determined according to the height measurements available in 2002: height at the end of 1997 and 2001 in Sillégny and at the end of 1996 and 2001 in La Petite Charnie (Fig. 1). Consequently, the part of the trunk studied corresponded to 4 annual shoots (AS) on trees at the Sillégny site and to 5 AS on trees at the La Petite Charnie site. In order to easily compare the data from both sites, they have been expressed per meter of trunk.

Four epicormic types were recorded according to the typology described by Fontaine et al. (2004): (1) isolated bud; (2) epicormic shoot; (3) "picot" and (4) cluster of buds (Fig. 2). We described their location on the trunk: at branch base, on the scale-scar rings, and on lateral position along the GU out of the two previous locations (Fig. 1).

Statistical analyses were completed with SAS v8.1. The independent variables and factors explaining the counts of epicormics per meter were selected with the help of the Poisson regression (procedure PROC GENMOD), taking account of over-dispersion (DSCALE statement). The dependent variables and factors tested were: provenance, Growth(provenance), number of branches per meter (NBRM), number of GU limits per meter (NGUM) and interactions. Once the variable and factors retained, we decided to fit a "classic" linear model that returned us a $R^{2}$ value. This value named " $R^{2}$ " gave a rough estimation of the proportion of the variability of the data explained by the selected variables and factors. This methodology was applied also to the number of branches per meter as well as to the number of GU limits per meter.

In addition, to get a more genetic meaning for our results, we also analyzed our data with the fitting constant method or Henderson's method 3 (Henderson, 1953). We then computed $Q_{\mathrm{ST}}$ which is defined as $V_{\mathrm{b}} /\left(V_{\mathrm{b}}+2 V_{\mathrm{w}}\right)$, where $V_{\mathrm{b}}$ and $V_{\mathrm{w}}$ are, respectively, the between-population and the additive within-population components of variance for the considered trait (Spitze, 1993). $Q_{\mathrm{ST}}$ values were then compared to known $F_{\mathrm{ST}}$ values; $Q_{\mathrm{ST}}$ and $F_{\mathrm{ST}}$ are common parameters used in population genetic which measure the differentiation between populations, $Q_{\mathrm{ST}}$ being dedicated to quantitative markers and $F_{\mathrm{ST}}$ to molecular markers (Hartl and Clark, 1997). $Q_{\mathrm{ST}}$ is widely used to assess the relative importance of selection and drift as determinants of genetic differentiation for quantitative traits (Lopez-Fanjul et al., 2007). For neutral genes with additive gene action between and within loci, $Q_{\mathrm{ST}}$ is the quantitative analogue of $F_{\mathrm{ST}}$. Otherwise, divergent or convergent selection is invoked, respectively, as a cause of the observed increase $\left(Q_{\mathrm{ST}}>F_{\mathrm{ST}}\right)$ or decrease $\left(Q_{\mathrm{ST}}<F_{\mathrm{ST}}\right)$ of $Q_{\mathrm{ST}}$ from its neutral expectation $\left(Q_{\mathrm{ST}}=F_{\mathrm{ST}}\right)$.

Finally we decided not to provide tables on the ranking of provenances as this ranking was different according to the site and to the trait considered. We only cited in the text the most important provenances in each case.

\section{RESULTS}

\subsection{Main features of the sample trees according to provenance and experimental sites}

All results are synthesized in Figure 3.

Depending on provenance, the shoot length described ranged between 150 and $250 \mathrm{~cm}$ in La Petite Charnie and 


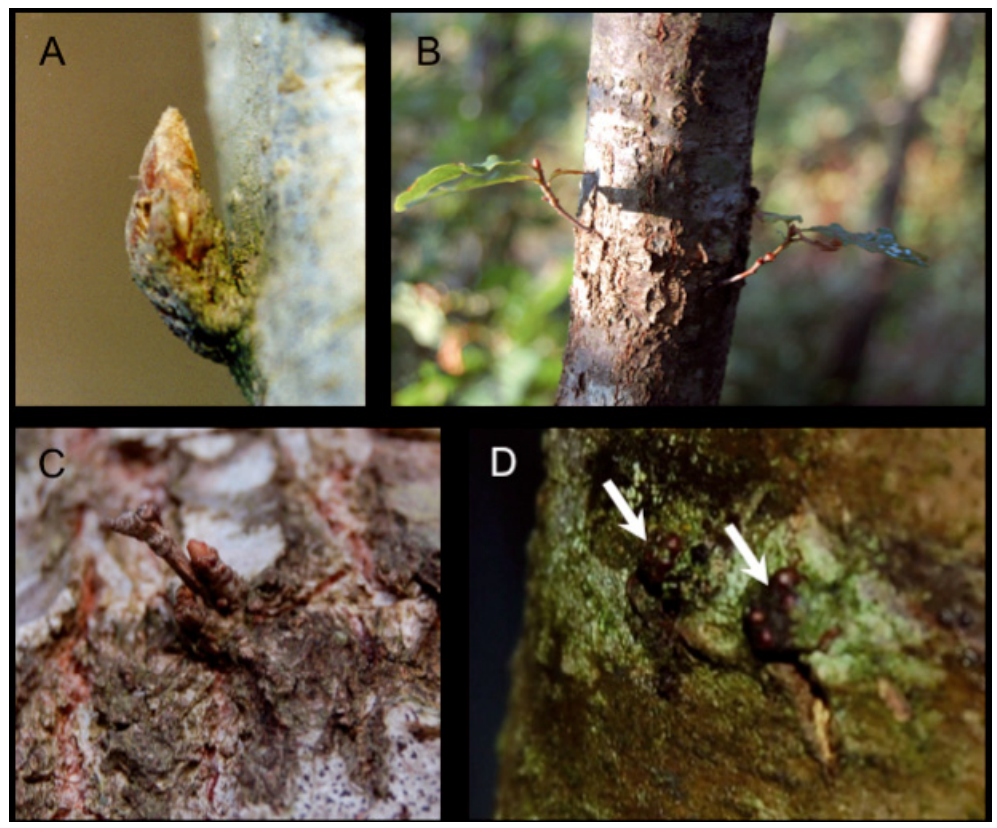

Figure 2. Four epicormic types: (A) isolated bud (length: $4 \mathrm{~mm}),(B)$ epicormic shoot (length: $10 \mathrm{~mm})$, (C) "picot" (French term) which is a very small stump of a shoot with epicormic buds (length: $5 \mathrm{~mm}$ ), and (D) cluster of buds where buds were directly inserted on the trunk (length: $4 \mathrm{~mm}$; bud: $1 \mathrm{~mm}$ ).

Table IV. Models of branch number and growth unit limits per meter depending on the site (values of " $R$ ")).

\begin{tabular}{lcccc}
\hline & \multicolumn{2}{c}{ La Petite Charnie } & \multicolumn{2}{c}{ Sillégny } \\
Prov & $\begin{array}{c}\text { Prov, } \\
\text { Growth (prov) }\end{array}$ & Prov & $\begin{array}{c}\text { Prov, } \\
\text { Growth (prov) }\end{array}$ \\
\hline $\begin{array}{l}\text { Number of } \\
\text { branches / m }\end{array}$ & 0.10 & 0.32 & 0.04 & 0.26 \\
$\begin{array}{l}\text { Number of growth } \\
\text { unit limits / m }\end{array}$ & 0.03 & 0.41 & 0.09 & 0.19 \\
\hline
\end{tabular}

between 100 and $200 \mathrm{~cm}$ in Sillégny. This difference was due to the fact that 5 annual shoots were observed in La Petite Charnie and 4 in Sillégny. Neither in La Petite Charnie nor in Sillégny, there was a provenance effect on the shoot length $(P$-value $=0.10$ and 0.29 respectively $)$.

About the number of branches per meter we can observe in Table IV that:

- it was generally larger in Sillégny (between 15 and 30) than in La Petite Charnie (between 10 and 25);

- there was a significant but small provenance effect in each site (Sillégny: $P$-value $=0.047, " R^{2} "=0.04$; La Petite Charnie: $P<0.0001$, " $\left.R{ }^{2} "=0.10\right)$;

- the ranking of the provenances is different in each site; for instance in La Petite Charnie, the two provenances with the largest values were 249 (Bolu) and 218 (Longchamp) and the provenance with the smallest value was provenance 219 (Tronçais); in Sillégny, provenance 249 (Bolu, polycyclic) had the highest values while the provenances with the lowest values were provenances 209 and 219 (Sturzelbronn and Tronçais); if the "Growth" effect was considered, the " $R$ " reached 0.32 and 0.26 in La Petite Charnie and Sillégny respectively.

About the number of GU limits per meter (Tab. IV):

- it was higher in La Petite Charnie (between 3 and 6.5) than in Sillégny (between 2.5 and 5.5);

- the provenance effect was significant in both sites (La Petite Charnie: $P$-value $=0.02, " R^{2} "=0.03$; Sillégny: $P$-value $<0.0001$, " $R{ }^{2}$ " $=0.09$ );

- the ranking was different in the two sites: in La Petite Charnie, provenances 218 (Longchamp) and 217 (Bercé) had the highest mean values; surprisingly, the Bolu provenance (249) which is known for its polycyclism did not have more GU limits than the other provenances; in Sillégny, both provenances 219 (Tronçais) and 233 (Vachères) showed the largest values;

- the "Growth" effect together with the provenance effect accounted for $41 \%$ of the variability in La Petite Charnie and $19 \%$ in Sillégny.

\subsection{Percentage of the different types of epicormics}

Among all epicormics, 95\% were epicormic buds in both La Petite Charnie and Sillégny sites (Tab. V).

The distribution of the frequencies of epicormics was statistically different between La Petite Charnie and Sillégny (Chi-square test: $P$-value $<0.0001$ ): proportionally more buds at branch base in Sillégny and more on GU limits in La Petite Charnie (Tab. V). In details, more than $50 \%$ of the epicormics were epicormic buds located at branch base: $51 \%$ in La Petite Charnie and $57 \%$ in Sillégny. The second most frequent type 
Stem

length on which epicormics have been tallied
La Petite Charnie

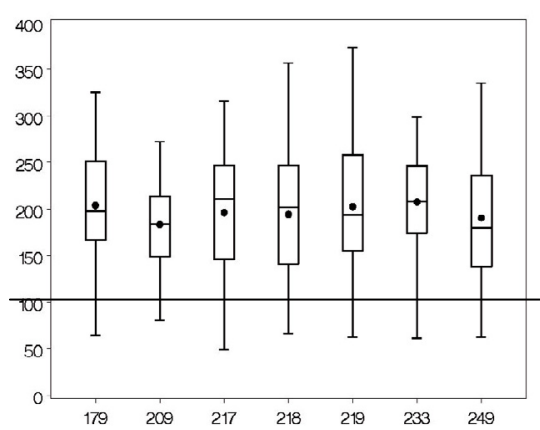

Frequency of
branches
per meter

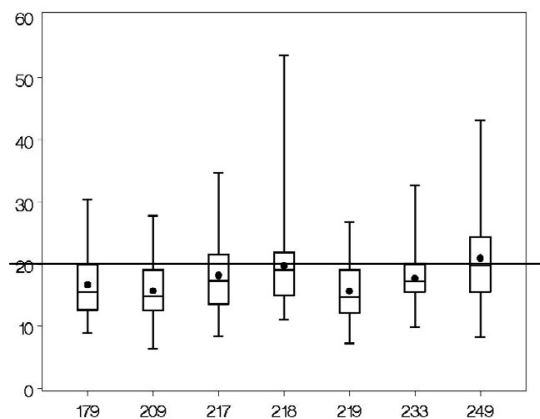

Frequency of GU limits per meter

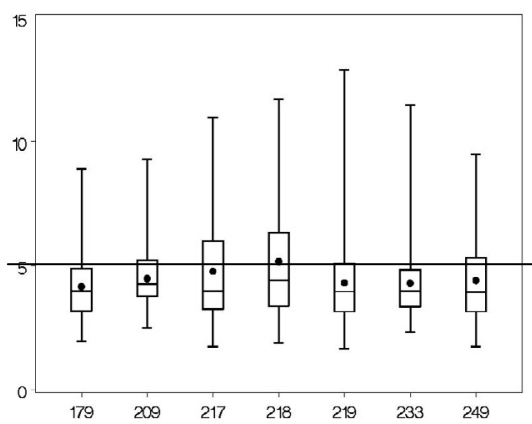

Sillégny
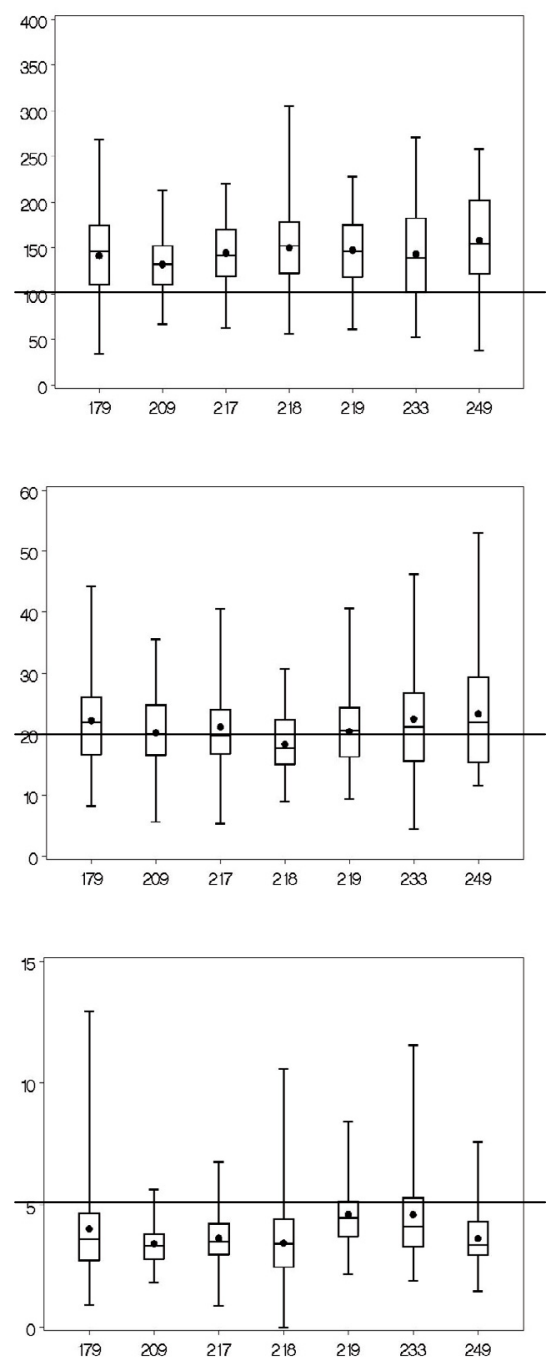

Figure 3. Box-plots of the main descriptors of the GUs per provenance on the two experimental sites. Horizontal lines help in comparing both sites.

Table V. Proportions of the different types of epicormics in the two experimental sites.

\begin{tabular}{llcc}
\hline \multicolumn{1}{c}{ Types } & La Petite Charnie & Sillégny \\
\hline Epicormic & Buds in branch base & 0.51 & 0.57 \\
buds $\quad$ Buds on growth unit limits & 0.25 & 0.20 \\
& Lateral buds & 0.19 & 0.18 \\
Epicormic shoots & 0.02 & 0.03 \\
"Picots" & 0.02 & 0.01 \\
Bud "clusters" & 0.01 & 0.01 \\
\hline
\end{tabular}

of epicomics was buds on GU limits, which represented $25 \%$ in La Petite Charnie and $20 \%$ in Sillégny. Lateral buds were in third position with around $18-19 \%$ in both sites. The proportion of the other types including epicormic shoots, "picots" and bud clusters was very low, near $5 \%$.
According to Figure 3 indicating that the proportions of epicormics types other than epicormic buds were very low, it has been decided to provide only the results of the counts per meter of: (1) all epicormics, (2) all epicormic buds and (3) epicormic buds located at branch base, on GU limits and on lateral position.

\subsection{Main features of the epicormic buds according to provenance and experimental sites}

About the total number of epicormic buds per meter, we observed that (Fig. 4):

- it was generally higher in Sillégny (between 35 and 90) than in La Petite Charnie (between 30 and 60);

- there was a significant provenance effect although lower in La Petite Charnie $(P$-value $=0.024$ versus $P$-value $<0.0001$ in Sillégny); 
La Petite Charnie

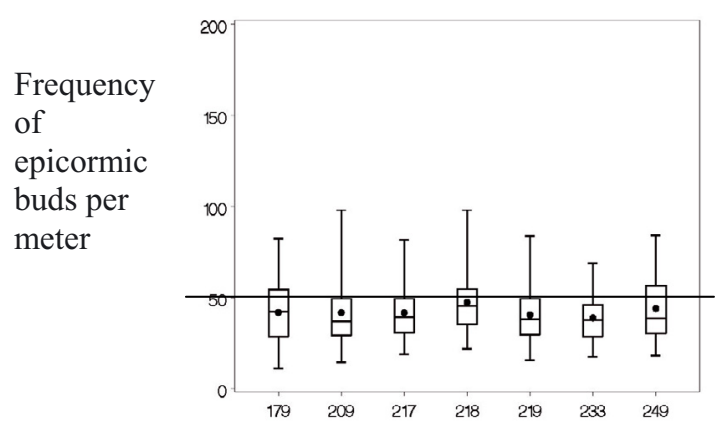

Frequency

of

epicormic

buds at

branch

base per

meter

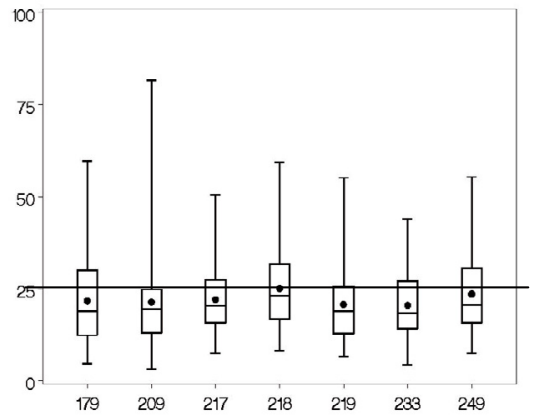

Frequency

of

epicormic buds at

GU limits per meter

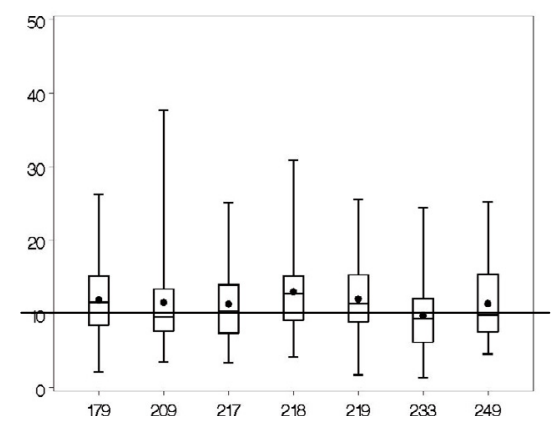

Sillégny
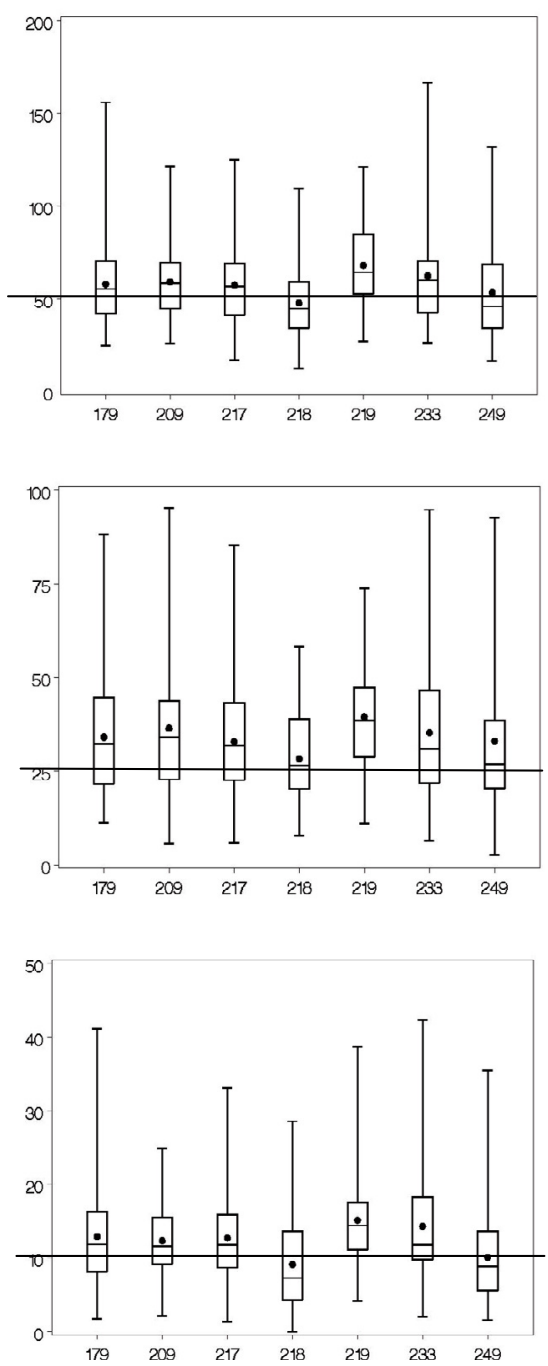

Figure 4. Box-plots of the main epicormic variables per provenance on the two experimental sites. Horizontal lines help in comparing both sites.

- the ranking of provenances was different: in La Petite Charnie, provenances with slightly larger values were 218 (Longchamp) and 249 (Bolu); in Sillégny, provenance 218 had the smallest value and provenance 219 (Tronçais) the largest.

About buds at branch base, their number was not significantly different between provenances in La Petite Charnie (Chi-square test: $P$-value $=0.22$ ) while it was significantly different in Sillégny (Chi-square test: $P$-value $=0.01$ ) with the largest values for provenance 219 (Tronçais) and the smallest for provenance 218 (Longchamp).

About epicormic buds located on GU limits, the provenance effect was significant in both Sillégny (Chi-square $P$-value $<0.0001)$ and La Petite Charnie (Chi-square $P$-value $=0.03)$. In La Petite Charnie, provenance 218 (Longchamp) and also 179 (Sycow) and 219 (Tronçais) had the largest values whereas in Sillégny provenance 218
(Longchamp) had the smallest values and provenance 219 (Tronçais) the largest. This result is to be linked with the fact that the ranking of numbers of GU was completely different in both sites.

\subsection{Variables and factors influencing the number of epicormics}

According to the results presented in Table $\mathrm{V}$, isolated buds represented around $95 \%$ of the total number of epicormics while buds at branch base represented slightly more than $50 \%$ and buds on GU limits around 20-25\%. Consequently, we decided to search the explicative variables and factors only for the total number of epicormic buds, the number of buds at branch base and the number of buds on GU limits. Since the results were similar for both the total number of epicormics and the total number of buds, the latter was thus only presented. 
Table VI. Main features of the selected models in both La Petite Charnie and Sillégny. Each line corresponds to one model. Data result from 446 observations in La Petite Charnie and 399 in Sillégny. Prov: provenance; NGULM: number of growth unit limits per meter; NBRM: number of branches per meter.

\begin{tabular}{|c|c|c|c|c|}
\hline Sites & Dependent variables & Variables and factors tested & $P$-value (Chi-square test) & $" R^{2} "$ \\
\hline \multirow{9}{*}{ La Petite Charnie } & Total number of epicormic buds per $\mathrm{m}$ & Prov & 0.10 & - \\
\hline & & Growth(prov) & $<0.0001$ & 0.14 \\
\hline & & NBRM, NBRM*Growth(prov) & $<0.0001$ & 0.36 \\
\hline & Number of buds at branch base per $m$ & Prov & 0.22 & - \\
\hline & & Growth(prov) & 0.003 & 0.08 \\
\hline & & $\begin{array}{l}\text { NGULM, NBRM, } \\
\text { NBRM*Growth(prov) }\end{array}$ & $<0.0001$ & 0.39 \\
\hline & Number of buds at GU limits per me & Prov & 0.03 & 0.03 \\
\hline & & Growth(prov) & $<0.0001$ & 0.17 \\
\hline & & $\begin{array}{l}\text { NGULM, NBRM, } \\
\text { NGULM*Growth(prov) }\end{array}$ & $<0.0001$ & 0.39 \\
\hline \multirow{10}{*}{ Sillégny } & Total number of epicormic buds per $\mathrm{m}$ & Prov & $<0.0001$ & 0.06 \\
\hline & & Growth(prov) & 0.004 & 0.10 \\
\hline & & NGULM, NBRM, Growth(prov) & $<0.0001$ & 0.21 \\
\hline & Number of buds at branch base per $\mathrm{m}$ & Prov & 0.01 & 0.04 \\
\hline & & Growth(prov) & 0.03 & 0.08 \\
\hline & & NBRM, NBRM*Growth(prov) & $<0.0001$ & 0.21 \\
\hline & Number of buds at GU limits per m & Prov & $<0.0001$ & 0.08 \\
\hline & & Growth(prov) & $<0.0001$ & 0.17 \\
\hline & & NBRM, NGULM, Growth(prov) & $<0.0001$ & 0.47 \\
\hline & & NGULM*Growth(prov) & & \\
\hline
\end{tabular}

Table VII. $Q_{\mathrm{ST}}$ values for three most important characters in the two provenances sites.

\begin{tabular}{lcc}
\hline Characters & La Petite Charnie & Sillégny \\
\hline $\begin{array}{l}\text { Number of buds at branch base } \\
\text { per meter }\end{array}$ & 0.039 & 0.023 \\
$\begin{array}{l}\text { Number of buds at GU limits } \\
\text { per meter }\end{array}$ & 0.051 & 0.059 \\
$\begin{array}{l}\text { Total number of epicormic buds } \\
\text { per meter }\end{array}$ & 0.060 & 0.051 \\
Means & 0.050 & 0.044 \\
\hline
\end{tabular}

When considering the " $R$ " value, the provenance effect was very small in both La Petite Charnie and Sillégny (Tab. VI). The "Growth" effect taken into account nested within the provenance effect was significant (but with " $\left.R^{2} "<0.15\right)$. This was essentially accounted for by morphological traits including the number of GU limits per meter (NGULM), the number of branches per meter (NBRM) and sometimes the interaction between the number of branches and the "Growth" effect.

\subsection{Genetic differentiation between populations}

Table VII provides the $Q_{\mathrm{ST}}$ values. The mean $Q_{\mathrm{ST}}$ (calculated for the three epicormic types as in the previous paragraph) was 0.050 in La Petite Charnie and 0.044 in Sillegny. For all characters, the $Q_{\mathrm{ST}}$ ranged from 0.023 to 0.060 .

\section{DISCUSSION}

Despite the importance of $Q$. petraea for European forestry and the impact of epicormics on its wood quality, there have been few attempts at testing and quantifying the relationship between provenance and epicormics. Our results show a significant but small effect of provenance on epicormics, especially on epicormic buds. Epicormic buds were mainly located at branch bases and on GU limits. The "Growth" effect (nested in the provenance effect) was clearly higher than the provenance effect.

Figure 5 is a schema of the results gained in the present study and of research perspectives. It will illustrate the following comments.

\subsection{Epicormics are mainly buds}

Our results show that on the growth units studied, epicormics were almost isolated epicormic buds at 95\%; clusters of buds, transient shoots (Colin et al., 2008) and "picots" represented only $5 \%$ (Tab. V, Fig. 5 (1)). The presence of buds especially could be explained mainly by the youth of the growth units described, between 2 and 6 years old, and also by the youth of the sample trees, 13-year-old. Every year, the apical bud develops into a growth unit that bears several axillary buds. One year after, on average around one third of the buds develop into sequential branches, one third of them die and fall and the last third remains as buds (Fontaine et al., 2001). The latter could be maintained as bud during several years, at least 


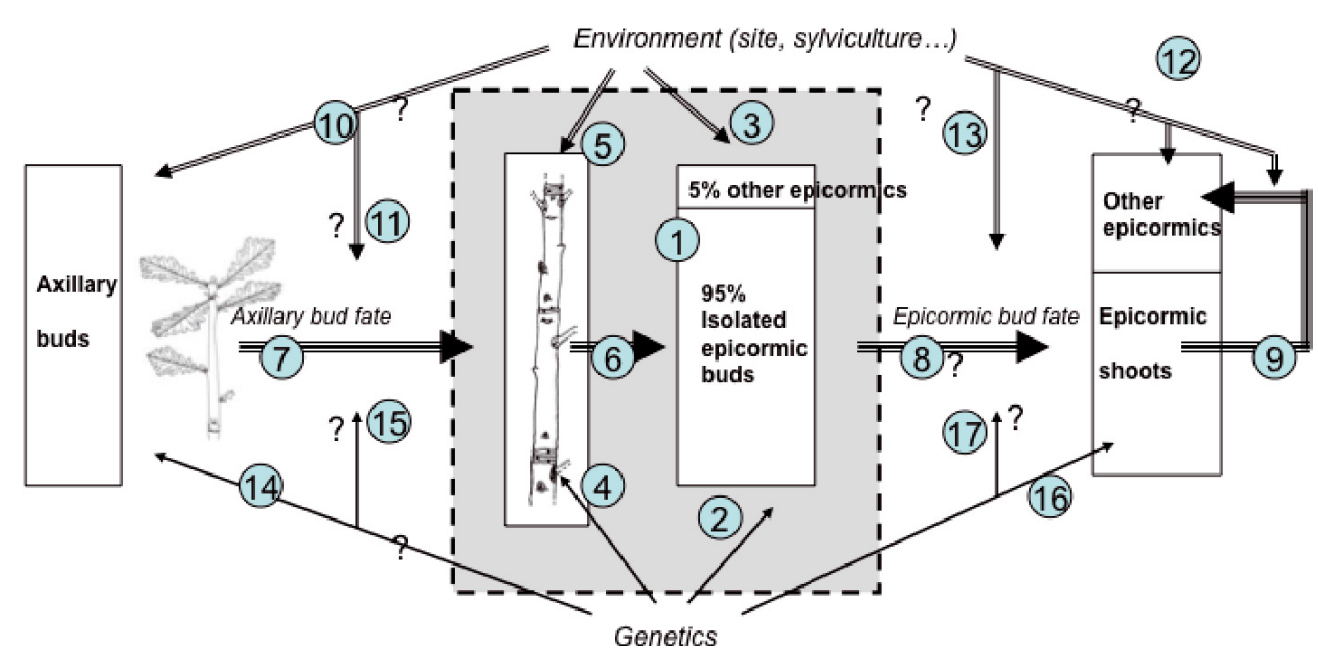

Figure 5. Synthesis of the results in the present study within the central frame and research perspectives. The horizontal arrows in triple line illustrate the ontogenic effect while the environmental effects are illustrated with double line and bold arrows, respectively. For the explanation of the numbers, see text.

40 years (Fontaine et al., 1999). Nevertheless, they could also develop into shoots especially after silvicultural practices like thinning (Wignall and Browning, 1988) or pruning (O'Hara and Valappil, 2000). In our case, the absence of silvicultural operations in both sites may explain the persistence as bud. To our knowledge, no-one except Smith (1966) reported frequencies of buds; almost all available studies take into account only epicormic branches, probably because the knots they form are thought to be the main elements which strongly depreciate timber quality (Fontaine et al., 2004; Jemisson and Schumacher, 1948; Remphrey and Davidson, 1992). The trees sampled in these studies were older than in our experiment, more than 20-year-old, and probably bore more epicormic shoots. In addition, the studied portion was often the entire trunk (Jensen, 1993; 2000) while our study considered only the top growth units still within the living crown.

\subsection{A small effect of provenance and a slightly larger "Growth" effect on the epicormics}

Our results show a very low provenance effect (Tab. VI, Fig. 5 (2)). In addition if we consider the $Q_{\mathrm{ST}}$ values (Tab. VII), it can be observed that they were slightly larger than the $F_{\mathrm{ST}}$ values, ranging from 0.023 to 0.044 for sessile oak (Mariette et al., 2002). $Q_{\mathrm{ST}}$ values equal to or slightly larger than $F_{\mathrm{ST}}$ values means that these traits are respectively neutral (concerning number of buds at branch base) or weakly selected with a divergent selection (concerning number of buds at GU limits per meter and total number of epicormic buds per meter).

Beside the low provenance effect, Table VI and Figure 5 (3) highlight a slightly larger "Growth" effect. The fact that genetic patterns may be blurred by environmental effects was also reported by Jensen (2000) in both $Q$. petraea and Q. robur.

\subsection{Provenance and growth situation effects on branches and GU limits}

We found provenance and "Growth" effects larger on GU limits and branch numbers than on epicormics in both sites (Tab. IV, Fig. $5(4,5)$ ). About the provenance effect, trends were different according to the site that prevents from ranking the provenances. Nevertheless, 3 provenances could be retained: the 2 famous ones (known for the good quality of their wood), Longchamps (218) and Tronçais (219) and the polycyclic one, Bolu (249). Indeed, the number of branches was the largest for provenance 218 in La Petite Charnie while it was the smallest in Sillégny. Provenance 218 shows also a larger number of GUs in La Petite Charnie whereas it was intermediate in Sillégny. The other famous provenance, provenance 219, showed also different results in both sites but they were different from those observed for provenance 218 . The Turkish provenance Bolu (249) assumed as highly polycyclic, did not develop more GU limits than the provenance Sycow-Richtal (179) which is monocyclic, whatever the site considered. Conversely, provenance Bolu (249) produced the larger number of branches in both La Petite Charnie and Sillégny. From this observation, one cannot neglect the possibility that some GU limits were hidden by branch insertions.

In contrast to the quite low effect of provenance, the "Growth" effect was highly significant on branch and GU limit numbers, independently from provenance (Tab. IV, Fig. 5 (5)). Indeed, it is well demonstrated that environment including fertility, light and climate controls both polycyclism (Chaar and Colin, 1999; Heuret et al., 2000) and branching (Collet et al., 1997; Harmer, 1989; Heuret et al., 2003).

\subsection{Importance of branches and GU limits on epicormic buds}

Our study revealed that epicormic buds, which represented $95 \%$ of the epicormics were essentially isolated buds and 
mainly located at branch bases (more than 50\%), secondarily on GU limits and marginally on lateral position (Tab. V, Fig. 5 (1)). This suggests the importance of polycyclism - reported by Harmer (2000) - and of sequential branches which bear secondary epicormic buds - already reported by Ward (1966) and Church and Godman (1966) (Fig. 5 (6)). The number of epicormic buds was only slightly larger in Sillégny than in La Petite Charnie. This could be explained by a number of branches in Sillégny larger than in La Petite Charnie, compensated for by a larger number of GU limits in La Petite Charnie than in Sillégny. A certain incoherence appeared concerning the number of branches: from the assessment after ten years (Tab. III), Sillégny site had less branches than La Petite Charnie site. From our observation, Sillégny site had more branches (Fig. 4). This apparent incoherence may be due (i) to the way the number of branches have been calculated: number of branches on entire trees in the former, number of branches per meter on the 4 annual shoots in Sillégny and 5 annual shoots in La Petite Charnie in the latter and (ii) to the number of replicates, all replicates in the former, only 3 replicates in the latter. Due to the strong structural relationship between epicormic buds, GU limits and branches, we assume that the provenance and the "Growth" effects were indirect effects on epicormics through GU limits (polycyclism) and branch numbers. Consequently, when including GU limits and branch numbers in the statistical model of epicormic buds, the " $R$ " " increased strongly.

The hypothesis that the more polycyclic the provenance and the more GU limits are found on every annual shoot, the more epicormics are located on GU limits, could not be validated. In particular, provenance Bolu (249) considered as polycyclic did not develop more epicormics than provenance Sycow-Richtal (179) which is monocyclic. The number of GU limits was similar in those 2 provenances and also, it was intermediate compared to the other provenances. This suggests either a non-expression of the parameter mono- or poly-cyclic growth in our sample sites or a failure in the GU limits detection. The GU limits could have been hidden by the insertion of the branches in the top part of each GU. This assumption could be relevant since provenance Bolu (249) produced the highest number of branches in both sites. In contrast, our results show that polycyclism was correlated to the "Growth" situation: independently from provenance, trees that grew in the situation with the largest growth rate developed more GU limits per year.

We formulated another hypothesis: the more famous is a provenance (based on its wood quality), the less epicormics it bears. The three "famous" provenances chosen, Bercé (217), Longchamp (218) and Tronçais (219), cannot confirm this hypothesis. The effect of the growth situation was more important and directly affected the number of branches (Tab. IV). This could suggest an effect of the site (combination of both climate and soil) where provenances are located. Considering the climate of the origin area and the phenology of provenances (Tab. III), no trend could be observed for the number of epicormic buds; these provenances were intermediate.

Related to the "Growth" effect, we observed a general site effect. The sample trees selected in Sillégny had more branches, less GUs, more epicormics, more epicormic buds at branch base. Sillégny being the most hydromorphic site we could have thought that hydromorphy promotes apical bud mortality inducing a loss of apical dominance. More axillary buds would become sequential branches and thus more epicormic buds would be present at their base in Sillégny. This interpretation coherent with our observations must be carefully tested since the general assessment made on all replicates in 1999 (Tab. III) show a reverse trend: more branches in La Petite Charnie.

\subsection{Towards general framework and methodologies for epicormic studies}

We propose to distinguish three main determinisms of epicormic prevalence: ontogeny, environment including silviculture, and genetics.

About ontogeny, the present study is located on a specific segment of ontogeny and highlights the predominant effect of morphological traits. "Upstream" must be investigated axillary bud fate (Fig. 5 (7)) and more "above" their setting parallel to height growth. "Downstream" must be investigated the fate of epicormic buds (Fig. 5 (8)) particularly through their dormancy and more "below" the renewal of epicormic buds from secondary buds inserted at epicormic shoot bases (Fig. 5 (9)). Indeed, epicormic buds have a weak intensity of endodormancy (definition from Lang, 1987) as demonstrated on several broadleaves (Champagnat, 1983; Mauget, 1984; Ricaud et al., 1995; Wignall et al., 1987). During the growth period, when the climatic conditions are satisfying (no ecodormancy), the epicormic bud burst is only under the influence of paradormancy.

About environmental effects on this ontogeny, on the "upstream" segments (Fig. $5(10,11)$ ), it must be cited all the factors that monitor early height growth i.e. light and soil resources (Chaar and Colin, 1999; Collet et al., 1997; Harmer, 1989; Heuret et al., 2000; 2003), browsing, defoliation (Chaar et al., 1997) and frost damages (Chaar and Colin, 1999). One must pose the questions: is it better to let grow fast the stem with long annual shoots and likely polycyclism or to monitor a slower height growth with shorter annual shoots and less polycyclism? Is it possible to reduce the sequential branching by manipulating the environment of the seedlings? We found no information on an eventual "Growth" effect on axillary bud fate. On the "downstream" segments (Fig. $5(12,13)$ ), it is known that the paradormancy can be easily broken by environmental factors which sometimes abruptly damage or weaken organs above the epicormic buds: defoliation, artificial or accidental girdling and pruning, flooding and water status (Arora et al., 2003; O'Hara and Valapil, 2000; Wignall et al., 1987).

On all ontogenic segments and on the various types of epicormics produced, genetics may have an influence (Fig. 5 (14 to 17)). Our study confirms the few data in the literature documenting a generally quite low provenance effect on the epicormics (Fig. 5 (16, 17)) (Jensen, 2000). But it must be noticed that our study concerns mainly epicormic buds and not 
epicormic shoots. In the literature, the provenance effect concerns epicormic shoots. In fact there is a great difference between epicormic buds and epicormic shoots: in the former case the genetic effect concerns the setting of buds linked to the stem elongation (Harmer, 1989) and the interaction with environmental factors controlling it; in the latter the genetic effect would concern both these previous features and also the phenomenon of bud burst, subsequent elongation of the epicormic shoots and the interaction with the factors controlling them. Thus the existence of a genetic effect on bud burst could be inferred, linked to the provenance effect on phenology. The latter has been well documented (Scotti-Saintagne et al., 2004).

A low provenance effect may indicate a high variability between individuals within a given provenance. Genotypes with a few epicormics must be thus searched at progeny level (Jensen et al., 1997). QTL identification could be undertaken; this identification has been already completed on phenology and early height growth of oak (Scotti-Saintagne et al., 2004), sequential branching (Shepherd et al., 2002) as well as latent buds (Segura et al., 2009).

\section{CONCLUSIONS}

This study highlighted the main effect of height growth components, the low effect of provenances and the higher effect of environment.

For the moment, our results provide very few practical advices for foresters who wish to reduce the epicormic problem. In particular, we cannot recommend specific provenances adapted to given stand situation. Conversely, a thorough selection as early as possible of individuals with few epicormic buds could be a relevant precaution. Situations of high risk of stem damages and of growth limitations must be avoided in the youth. All silvicultural means leading to a good lateral shelter against frost, a moderate initial competition, a moderate shading and an efficient protection against game must be promoted. These proposals are preliminary and must be carefully tested.

Acknowledgements: We would like to thank Jean Marc Louvet, Michel Verger, Marc Faucher and Dominique Veisse from the Experimental Unit in INRA Orleans, in charge of the management of La Petite Charnie experiment; Pierre Legroux, Alain Nassau and Fabrice Bonne from the Experimental Unit UEFL in INRA Nancy, in charge of the management of Sillégny experiment; Patrick Pastuszka from the Experimental Unit in INRA Bordeaux; Jeanne-Luce Sakanga-Siatemoko for statistical analysis; Pascal Jarret (ONF Orléans) for provenance selection and generally for scientific support; especially the following people who did measurements in 2002: Alain Nassau, Fabrice Bonne, Thierry Paul, Roland Herbeck, Bruno Garnier, Sébastien Daviller, Matthieu Dassi temporary employee, and Sylvie Ricord for English corrections. This project was supported by the National Forest Service (ONF).

\section{REFERENCES}

Arora R., Rowland L.J., and Tanino K., 2003. Induction and release of bud dormancy in woody perennials: a science comes of age. HortScience 38: 911-921.
Barthélémy D. and Caraglio Y., 2007. Plant architecture: a dynamic, multilevel and comprehensive approach to plant form, structure and ontogeny. Ann. Bot. 99: 375-407.

Chaar H. and Colin F., 1999. Impact of late frost on height growth in young sessile oak regenerations. Ann. Sci. For. 56: 417-429.

Chaar H., Colin F., and Leborgne G., 1997. Artificial defoliation, decapitation of the terminal bud, and removal of the apical tip of the shoot in sessile oak seedlings and consequences on subsequent growth. Can. J. For. Res. 27: 1614-1621.

Champagnat P., 1983. Quelques réflexions sur la dormance des bourgeons des végétaux ligneux. Physiol. Veg. 21: 607-618.

Church T.W. and Godman R.M., 1966. The Formation and development of dormant buds in sugar maple. For. Sci. 12: 301-306.

Colin F., Robert N., Druelle J.L., and Fontaine F., 2008. Initial spacing has little influence on transient epicormic shoots in a 20 -year-old sessile oak plantation. An. For. Sci. 65: 508.

Collet C., Colin F., and Bernier F., 1997. Height growth, shoot elongation and branch development of young Quercus petraea grown under different levels of resource availability. Ann. Sci. For. 54: 65-81.

Fink S., 1980. Anatomical studies on the occurrence of shoot and root primordia in the stem region of broadleaved and coniferous trees. 1. Proventitious primordia. Allg. Forst. Jagdz. 151: 160-180.

Fontaine F., Kiefer E., Clément C., Burrus M., and Druelle J.L., 1999. Ontogeny of proventitious epicormic buds in Quercus petraea. II. From 6 to $40 \mathrm{y}$ of the tree's life. Trees-Struct. Funct. 14: 83-90.

Fontaine F., Colin F., Jarret P., and Druelle J.L., 2001. Evolution of the epicormic potential on 17-year-old Quercus petraea trees: first results. Ann. Sci. For. 58: 583-592.

Fontaine F., Mothe F., Colin F., and Duplat P., 2004. Structural relationships between the epicormic formations on trunk surface and defects induced in the wood of Quercus petraea. Trees-Struct. Funct. 18: 295-306.

Harmer R., 1989. The effect of Mineral Nutrients on Growth, Flushing, Apical Dominance and Branching in Quercus petraea (Matt.) Liebl. Forestry 62: 383-395.

Harmer R., 2000. Differences in growth and branch production by young plants of two provenances of Quercus robur L. Forestry 73: 271-281.

Hartl D. and Clark A., 1997. Principles of Population Genetics. Sinauer Associates Inc., 542 p.

Henderson C.R., 1953. Estimation of variance and covariance components. Biometrics 9: 226-252.

Heuret P., Barthélémy D., Nicolini E., and Atger C., 2000. Analysis of height growth factors and trunk development in the sessile oak, Quercus petraea (Matt.) Liebl. (Fagaceae) in dynamic sylviculture. Can. J. Bot. 78: 361-373.

Heuret P., Guédon Y., Guérard N., and Barthélémy D., 2003. Analysing branching pattern in plantations of young red oak trees (Quercus rubra L., Fagaceae). Ann. Bot. 91: 479-492.

Jarret P., 2004. Chênaie atlantique : Guide des sylvicultures. ONF Ed., Lavoisier, Paris, 335 p.

Jemission G.M. and Schumacher F.X., 1948. Epicormic branching in oldgrowth Appalachian hardwoods. J. For. 46: 252-254.

Jensen J.S., 1993. Variation of growth in Danish provenance trials with oak (Quercus robur L and Quercus petraea Mattuschka Liebl). Ann. Sci. For. 50 (suppl 1): 203-207.

Jensen J.S., 2000. Provenance variation in phenotypic traits in Quercus robur and Quercus petraea in Danish provenance trials. Scand. J. For. Res. 15: 297-308.

Jensen J.S., Wellendorf H., Jager K., De Vries S.M.G., and Jensen V., 1997. Analysis of 17-year old dutch open-pollinated progeny trial with Quercus robur (L.). For. Genet. 4: 139-147.

Lang G.A., 1987. Dormancy: a new universal terminology. HorstScience 22: $817-820$. 
Lavarenne-Allary S., 1965. Recherche sur la croissance des bourgeons de chênes et de quelques autres espèces ligneuses. Ann. Sci. For. 22: 7-203.

López-Fanjul C., Fernández A., and Toro M.A., 2007. The Effect of dominance on the use of the $Q_{\mathrm{ST}}-F_{\mathrm{ST}}$ contrast to detect natural selection on quantitative traits. Genetics 176: 725-727.

Mariette S., Cottrell J., Csaikl U.M., Goikoechea P., Konig A., Lowe A.J., Van Dam B.C., Barreneche T., Bodenes C., Streiff R., Burg K., Groppe K., Munro R.C., Tabbener H., and Kremer A., 2002. Comparison of levels of genetic diversity detected with AFLP and microsatellite markers within and among mixed Quercus petraea (Matt.) Liebl. and Q. robur L. stands. Silvae Genetica 51: 72-79.

Mauget J.C., 1984. Comportement comparé des bourgeons de l'année et des bourgeons latents chez le noyer (Juglans regia L., cv. "Franquette"). Conséquences sur la morphogenèse de l'arbre. Agronomie 4: 507-515.

O'Hara K.L. and Valappil N.I., 2000. Epicormic sprouting of pruned western larch. Can. J. For. Res. 30: 324-328.

Ricaud S., Alaoui-Sossé B., Crabbé J., and Barnola P., 1995. Dormance et croissance des bourgeons du platane hybride (Platanus acertifolia) en milieu urbain. Can. J. Bot. 73: 130-140.

Remphrey W.R. and Davidson C.G., 1992. Spatiotemporal distribution of epicormic shoots and their architecture in branches of Fraxinus pennsylvatica. Can. J. For. Res. 22: 336-340.
Scotti-Saintagne C., Bodenes C., Barreneche T., Bertocchi E., Plomion C., and Kremer A., 2004. Detection of quantitative trait loci controlling bud burst and height growth in Quercus robur L. Theor. Appl. Genet. 109: 1648-1659.

Segura V., Durel C.E., and Costes E., 2009. Dissecting apple tree architecture into genetic, ontogenetic and environmental effects: QTL mapping. Tree Genet. Genomes 5: 165-179

Shepherd M., Cross M., Dieters M.J., and Henry R., 2002. Branch architecture QTL for Pinus elliotii var. eliottii x Pinus cariaea var. hondurensis hybrids. Ann. For. Sci. 59: 617-625

Smith H.C., 1966. Epicormic branching on eight species of Appalachian hardwoods. USDA Forest Service Note NE-53: 1-4.

Spitze K., 1993. Population structure in Daphnia obtusa: quantitative genetic and allozyme variation. Genetics 135: 367-374.

Stone E.L. and Stone M.H., 1943. "Dormant" versus "adventitious" buds. Science 98: 24-33.

Ward W.W., 1966. Epicormic branching of black and white oaks. For. Sci. 12: 290-297.

Wignall T.A. and Browning G., 1988. The effects of stand thinning and artificial shading on epicormic bud emergence in pedunculate oak (Quercus robur L.). Forestry 61: 46-59.

Wignall T.A., Browning G., and Mackenzie K.A.D., 1987. The physiology of epicormic bud emergence in pedonculate oak (Quercus robur $\mathrm{L}$.). Response to partial notch girdling in thinned and unthinned stands. Forestry 60: 45-56. 